\title{
O Deus de Caim: representações de poder e violência no romance de José Saramago
}

The God of Cain: representations of power and violence in José Saramago's novel

\author{
Janer Cristina MACHADO* \\ Universidade Federal de Santa Maria (UFSM)
}

\begin{abstract}
RESUMO: Poder e violência se encontram estreitamente ligados desde os primórdios da civilização, permeando, inclusive, o relacionamento entre o homem e o sagrado. Partindo desta constatação, o presente trabalho aborda as representações de poder e violência no romance Caim, de José Saramago, enfatizando a escritura do texto como um locus de denúncia e liberdade, na qual a voz de uma humanidade oprimida torna públicos os abusos de uma divindade que exerce sua autoridade sagrada de forma deturpada, pautando-se pelo uso da força e pelo cultivo da injustiça.
\end{abstract}

PALAVRAS-CHAVE: Poder. Violência. Divindade. Humanidade

ABSTRACT: Power and violence are closely linked since the dawn of civilization, permeating, including, the relationship between the man and the sacred. From this consideration, this paper discusses the representations of power and violence in the novel Caim, by Jose Saramago, emphasizing the writing of the text as a locus of denunciation and freedom, in which the voice of an oppressed humanity make public the abuses of a divinity that uses your sacred authority in a corrupted form, guided by the use of force and the cultivation of injustice.

KEYWORDS: Power. Violence. Divinity. Humanity

\section{Introdução}

As concepções de poder, com seus correlatos de autoridade e autoritarismo, assim como suas derivações de repressão e violência, acompanham a história humana desde os seus primórdios. Podemos afirmar que as relações de dominação e submissão fazem parte dos prospectos de convivência entre os seres humanos desde que os mesmos se conscientizaram das implicações de um modus vivendi gregário, quais sejam as de que em um grupo sempre se estabelecerão lideranças, com base na consolidação de posições de quem é o mais forte e de quem é o mais fraco.

Ao conceituar o poder, Arendt (1985, p.24) salienta:

O "poder" corresponde à habilidade humana de não apenas agir, mas de agir em uníssono, em comum acordo. O poder jamais é propriedade de um indivíduo; pertence ele a um grupo e existe apenas enquanto o grupo se mantiver unido. Quando dizemos que alguém está “no poder", estamos na realidade nos referindo

\footnotetext{
* Mestra em Letras - Estudos Literários pelo Programa de Pós-Graduação em Letras da Universidade Federal de Santa Maria, Especialista em História pela Universidade Federal de Santa Maria, Graduada em Letras Português e Literaturas da Língua Portuguesa pela Universidade Federal de Santa Maria, Técnica em Assuntos Educacionais com atuação junto à Unidade de Apoio Pedagógico, no Centro de Ciências Rurais da Universidade Federal de Santa Maria, RS. Email: janercris@ terra.com.br.
} 
ao fato de encontrar-se esta pessoa investida de poder, por um certo número de pessoas, para atuar em seu nome. No momento em que o grupo de onde se originara o poder (potestas in populo, sem um povo ou um grupo não há poder) desaparece, o "seu poder" também desaparece.

Sendo um fenômeno eminentemente coletivo, marcado pela vontade de um grupo, o poder se assume como instância essencialmente política, ainda que suas bases estejam na detenção de influência e/ou supremacia de natureza econômica ou cultural, as quais demandam, latu sensu, a hegemonia social.

Novamente de acordo com Arendt (1985, p.28), "O poder não precisa de justificativas, sendo inerente à própria existência das comunidades políticas: mas precisa, isto sim, de legitimidade". E, ao refletirmos sobre o peso que a vontade coletiva tem sobre a atribuição/ manutenção das posições de poder, faz-se patente a conclusão de que a legitimação do poder se verifica maçiçamente através do porte do que chamamos autoridade, instância que a filósofa alemã caracteriza como dotada de "reconhecimento sem discussões por aqueles que são solicitados a obedecer; nem a coerção e nem a persuasão são necessárias". A autoridade sumamente reconhecida se mantém enquanto existe o respeito pela pessoa ou pelo cargo que a mesma ocupa, morrendo quando se instaura o desprezo pelos mesmos (ARENDT, 1985, p.24-25).

Ao comentar o conceito de autoridade descrito por Arendt (1985), Perissinotto (2004, p.119) alerta:

O conceito de autoridade refere-se ao mais enganoso dos fenômenos políticos, pois descreve uma realidade aparentemente paradoxal. De um lado, identifica uma relação hierárquica de mando e obediência, mas que não se traduz em violência, isto é, não demanda o uso efetivo dos implementos para funcionar; de outro lado, não opera por meio da persuasão, pois não é uma relação igualitária, mas sim hierarquizada; quem obedece o faz por "respeito".

Ao poder que carece de bases para legitimação, aquele que eventualmente se concretiza iludindo a vontade coletiva, seja por meio da força ${ }^{1}$, seja via sofisticação de pesados aparatos ideológicos, torna-se natural e frequente o consórcio com o instrumental da violência. Como pontua Arendt (1985, p.28), "O poder e a violência, embora sejam fenômenos distintos, geralmente apresentam-se juntos. Onde quer que se combinem, o poder é, conforme verificamos, o fator fundamental e predominante". No entanto, é a própria violência que acaba por solapar o poder, pois tende a se apresentar apenas onde o mesmo encontra sua sustentabilidade ameaçada, o que deriva, ipsis literis, da carência de legitimidade, do estado de domínio construído sobre a manipulação das vontades.

$\mathrm{O}$ poder que se consolida como legítimo, que abona a autoridade e rechaça a violência, é o poder que emerge da polis, do consenso entre os cidadãos que interagem pelo destino comum do grupo, que deve ser a liberdade. Este poder, conforme Serejo (2008, p.7):

\footnotetext{
${ }^{1}$ Não trataremos aqui do conceito de força, assim como do de vigor, embora Arendt os apresente como correlatos das noções de poder, autoridade e violência. Para atender os propósitos deste estudo, centramo-nos nestes três últimos enquanto corolários para a identificação de representações que permeiam um determinado construto literário, considerando os dois primeiros como elementos integrantes dos mesmos e não nos atendo pura e exclusivamente às suas distinções, por as mesmas não interessarem aos objetivos de nosso trabalho (N.A).
} 
Atualiza-se quando não há dicotomia entre palavra e ação; quando as palavras estão repletas de sentido e a ação não manifesta a violência; quando, na ação, a palavra é realizada. Poder é a condição da existência do homem falante e atuante; dominação e violência são o espaço dos mudos e imobilizados.

Neste momento, sustentamo-nos nas concepções de Hannah Arendt e seus estudiosos para adentrar ao campo da metáfora existencial por excelência, a literatura. Aqui é nosso desejo abordar o construto literário de José Saramago (1922-2010): detentor privilegiado da palavra com sentido, para utilizarmos a feliz expressão de Serejo, o autor português incorporou o poder como manifestação do canto dos oprimidos, conformando sua escrita ao retrato das lutas entre dominadores e dominados, na qual o desejo de liberdade e de verdade sobrepuja a falácia dos antigos discursos em prol dos marcos intocáveis da sociedade - entre eles a religião.

Contemplando parte da criação saramaguiana, nosso objeto de estudo centra-se no romance Caim, que, publicado em 2009, constitui a derradeira obra do autor português. Ao reconstituir as peripécias do primogênito de Adão e Eva em seu conturbado relacionamento com a divindade, Saramago pinta uma fábula da luta humana contra seus próprios monstros, a qual é também a luta contra a instância nutriz de todas essas monstruosidades, a saber, uma potestade celeste que se erige como poder absoluto, ainda que despido de legitimidade. $\mathrm{O}$ duelo de razões e não-razões sustentado entre Caim e Deus nos permite identificar representações de poder e violência, as quais impregnam pensamentos, falas e ações de vítimas e algozes, em um círculo vicioso que dispõe criador e criatura como perpétuos contendores, ao mesmo tempo em que erige a liberdade da palavra como máxima prerrogativa no enfrentamento da tirania.

Partindo desta atualíssima releitura do drama bíblico, assim como norteando a essência de nossas concepções de poder, autoridade e violência pela breve resenha aqui apresentada da obra arendtiana, demandamos em primeiro lugar a investigação das representações de poder no romance saramaguiano, para, em seguida, traçarmos as ilações da violência com o périplo de Caim em sua inusitada viagem pelo tempo, viagem que conduz o protagonista ao questionamento da divindade como gestora dos destinos humanos. Pari passu à obra de Hannah Arendt (1985; 2000), nos utilizamos dos estudos filosóficos de Adorno sobre a personalidade autoritária, bem como recorremos aos respectivos vieses antropológico e psicológico de René Girard e Roger Dadoun, entre outros autores, para elucidar, em suas especificidades, a herança primordial de poder e violência que acompanham o ser humano desde os tempos de Adão e Eva.

\section{A litania do poder}

Na Sagrada Escritura, encontramos Caim como um dos primeiros personagens da epopéia humana, iniciada a partir da criação do homem no Gênesis. Enciumado com a manifesta preferência de Deus por seu irmão Abel, o primogênito de Adão e Eva decide assassiná-lo, sendo punido pela divindade com a imposição de uma permanente condição errante, ainda que Deus imponha-lhe um sinal distintivo que impeça os homens de tentarem agredi-lo ou matá-lo.

$\mathrm{Na}$ fábula saramaguiana, porém, Caim contesta a autoridade divina atribuindo a Deus parte da culpa pela morte do irmão, pois sustenta que não o teria assassinado se Deus tivesse aceitado suas oferendas e demonstrado por ele o mesmo apreço que revelara por Abel. O protagonista também acrescenta que Deus poderia ter impedido a morte de Abel se assim o quisesse, tal ato mostrando que o Senhor não é tão poderoso quanto quer que os homens acreditem. E legitima a revolta como única resposta possível ao homem esmagado 
pelos desígnios inescrutáveis da divindade: "Abençoados sejam os que escolheram a sedição, porque deles será o reino da terra [...]" (SARAMAGO, 2009, p. 34-35).

Em acirrado debate verbal com Deus, Caim é condenado pela divindade, como na Bíblia, a vagar sem destino pelo mundo, sendo também marcado por Deus com um sinal na testa, visando protegê-lo das punições advindas de outros homens. Tal ato, simultaneamente bênção e maldição, afasta Caim do castigo humano, reservando-o exclusivamente para o castigo divino, o qual o protagonista não teme, pois se relaciona com Deus de igual para igual, considerando-o um ser impiedoso, sanguinário e indigno da confiança e devoção dos homens.

Da peregrinação errante pela Terra de Nod (que do hebraico nodedin, significa "terra do nada" ou "terra da fuga"), Caim é misteriosamente catapultado para diversos momentos futuros da História Sagrada, conhecendo personagens como Abraão, Noé, Moisés, Josué, entre outros.

Em seu périplo pelos tempos futuros, que ele chama de "outros presentes", Caim experiencia continuamente as injustiças e arbitrariedades cometidas por Deus, que alimenta guerras e jogos de poder entre os homens, visando exclusivamente à satisfação de sua vaidade. No entanto, curiosamente, sobre o misterioso tráfego do amaldiçoado filho de Adão através do tempo, a divindade confessa não ter qualquer controle, inclusive ocorrem encontros entre o protagonista e Deus, como às vésperas da destruição de Sodoma e Gomorra, em que o Senhor sequer percebe que se encontra na presença do condenado assassino de Abel.

O exercício do poder pela divindade em Caim nos remete às concepções de Adorno (1950), na medida em que o filósofo alemão preconiza as frustrações de caráter psicológico, advindas dos anos de formação, como base da constituição de personalidades doentias, as quais somente se satisfazem mediante a práxis de uma autoridade deturpada, fundamentada na impulsividade e no solapamento de todos aqueles que se lhe opõem. Segundo Crochik (1990, p.147), parafraseando a palavra de Adorno (1950):

A personalidade autoritária que age predominantemente através de "impulsos irracionais" é ambivalente, ou seja, necessita manter e destruir ao mesmo tempo, embora esta destruição deva caminhar no sentido reacionário e não revolucionário. Assim, esta mudança se caracteriza pelo conservadorismo.

O autor continua (CROCHIK, 1990, p.148):

\begin{abstract}
Aquele que não conseguiu uma adequada identificação parental na infância, e teve dificuldades de introjetar os valores parentais, quando adulto tem de fazer um esforço suplementar para fortalecer em si mesmo e no meio, estes valores para se defender de sua ambivalência de impulsos e do consequente sentimento de culpa. Precisa, em outras palavras, fortalecer a autoridade e dirigir a sua agressão para os grupos que imagina que o ameaçam. Mas é importante enfatizar que os grupos nos quais projeta sua agressão são depositários de seus desejos, o que significa que agredir estes grupos é também autoagressão.
\end{abstract}

Neste sentido, o Deus de Caim é aquela potestade algo infantil, que reafirma constantemente seu status de todo poderoso através de jogos e testes com seu brinquedo favorito, a humanidade. Este Deus se pensa absoluto em sua simples condição de ser divindade, assumindo-se egocentricamente como alguém que dispensa definições ou complementos assessórios: "Eu sou o senhor, gritou, eu sou aquele que é" (SARAMAGO, 2009, p.16), sentencia o criador de Adão e Eva, cujos acessos de ira e contrariedade, surpreendentes "em quem tudo poderia ter solucionado com outro rápido Fiat" 
(SARAMAGO, 2009, p.9) traem a fragilidade de quem, no fundo, sabe-se menor do que realmente é. Alguém que precisa justificar suas dimensões divinas por meio da imposição do terror e da perplexidade sobre os demais.

O Deus com veleidades de criança brinca indiscriminadamente com as vidas de suas criaturas, comportando-se como um voyeur das existências que engendra, como provam as palavras que o primeiro casal da humanidade ouve de um querubim:

\begin{abstract}
Não sois os únicos seres humanos que existem na terra, começou. Que não somos os únicos, exclamou adão estupefato. Não me faças repetir o que já está dito, Quem foi que criou esses seres, onde estão, Em toda parte, Foi o senhor quem os criou como nos criou a nós, perguntou Eva, Não posso responder, e se insistem com a pergunta a nossa conversa acaba agora mesmo (...) Depois eva perguntou, Se já existiam outros seres humanos, para que foi então que nos criou o senhor, Já deveis saber que os desígnios do senhor são inescrutáveis, mas, se bem entendi alguma meia palavra, tratou-se de um experimento, Um experimento, nós, exclamou adão, um experimento, para quê, Do que não conheço de ciência certa não ousaria falar, o senhor lá terá suas razões para guardar silêncio sobre o assunto (SARAMAGO, 2009, p.26-27).
\end{abstract}

Os impulsos experimentais da divindade provam sua irracionalidade na medida em que manipulam vidas humanas sem quaisquer motivações que fiquem claras. A inescrutabilidade dos desígnios divinos coroa o desprezo pela vontade do outro, convertido em simples objeto do jogo daquele que detém o poder e que não vê necessidade de partilhar seus objetivos com os diretamente atingidos por eles, assim como não lhe importam as consequências que suas determinações possam ter sobre quem por elas é afetado. Tal estado de coisas se faz explícito, por exemplo, no episódio em que Deus discute com Caim, logo após o mesmo ter assassinado seu irmão:

\begin{abstract}
Mataste-o, Assim é, mas o primeiro culpado és tu, eu daria a vida pela vida dele se tu não tivesses destruído a minha, Quis pôr-te a prova, E tu, quem eres para pores à prova o que tu mesmo criaste, Sou o dono soberano de todas as coisas, E de todos os seres, dirás, mas não de mim nem da minha liberdade, Liberdade para matar, Como tu foste livre para deixar que eu matasse abel quando estava na tua mão evitá-lo, bastaria que por um momento abandonasses a soberba da infalibilidade que partilhas com todos os outros deuses, bastaria que por um momento fosses realmente misericordioso, que aceitasses a minha oferenda com humildade, só porque não deverias atrever- te a recusá-la, os deuses e tu, como todos os outros, têm deveres para com aqueles a quem dizem ter criado (SARAMAGO, 2009, p.34).
\end{abstract}

Aqui o discurso sedicioso de Caim é um libelo contra a tirania de uma divindade infantilizada e egocêntrica, desobrigada de suas responsabilidades para com suas criaturas, a quem se julga no pleno direito de colocar a prova conforme seu bel prazer. Este Deus revela permanentemente seu lado soturno e intenções nebulosas, recusando-se a corresponder à figura de um verdadeiro pai. Como pontua Caim: "deus deveria ser claro e transparente como cristal, em lugar desta contínua assombração, deste constante medo" (SARAMAGO, 2009, p.135).

Por outro lado, o exercício equivocado de autoridade da potestade inescrutável é veementemente contestado pelo poder da palavra, aquela que Serejo (2008), em sua leitura de Arendt, aponta como a verdadeira força motriz do poder legítimo, emanado da vontade do povo e instrumento por excelência na consecução da liberdade.

Contudo, se Caim resiste à dominação de uma autoridade que não reconhece como legítima, outros se acomodam aos desígnios arbitrários da mesma, constituindo 
arrevezamentos daquilo que se poderia classificar como justo e correto. São, em essência, cópias pálidas da própria divindade, seguidores fiéis e incapazes de contestar a vontade divina, para os quais podemos aplicar, em certa medida, as palavras de Adorno (2011, p.1):

[o homem autoritário] é ao mesmo tempo esclarecido e supersticioso, orgulhoso de ser um individualista e sempre temeroso de não ser igual aos outros, ciumento de sua independência e inclinado a se submeter cegamente ao poder e à autoridade.

Nesta categoria, se encontram os patriarcas retratados por Saramago: Abraão, que não hesita em sacrificar seu filho a um simples pedido de Deus; Noé, que sucumbe à soberba de ser o único homem justo na terra, capaz de escapar à chacina do dilúvio; Josué, que se consorcia à deidade para tramar ardis e conquistar a cidade dos gibeonitas, esmagando impiedosamente os inimigos; e mesmo Job, que se curva estoicamente ao castigo imerecido, demonstrando com isso, subliminarmente, uma certa vaidade em ser o servo cegamente devotado ao senhor. Mas estes ícones da perfeita servidão aos desejos do Altíssimo também demonstram sua parcela de insegurança no discurso que procuram tecer a favor de sua obediência cega à divindade. Leiamos o diálogo entre Abraão e Isaac, recém salvo da imolação pela providencial intervenção de Caim:

\footnotetext{
Pai, que mal eu te fiz para quereres matar-me, a mim que sou teu único filho, Mal não me fizeste Isaac, Então por que quiseste cortar-me a garganta como se eu fosse um borrego, perguntou o moço, se não tivesse aparecido aquele homem para segurar-te o braço, que o senhor o cubra de bênçãos, estarias agora a levar um cadáver para casa, A ideia foi do senhor que queria tirar a prova, A prova de quê, Da minha fé, da minha obediência, E que senhor esse que ordena a um pai que mate seu próprio filho, É o senhor que temos, o senhor dos nossos antepassados, o senhor que já cá estava quando nascemos, E se esse senhor tivesse um filho, também o mandaria matar, perguntou isaac, $\mathrm{O}$ futuro o dirá, Então o senhor é capaz de tudo, do bom, do mau e do pior, Assim é, Se tu tivesses desobedecido à ordem, que sucederia, perguntou isaac, $\mathrm{O}$ costume do senhor é mandar a ruína ou a doença a que lhe falhou, Então o senhor é rancoroso, Acho que sim, respondeu Abraão em voz baixa, como se temesse ser ouvido, ao senhor nada é impossível, Nem um erro ou crime, perguntou isaac, Os erros e os crimes sobretudo (SARAMAGO, 2009, p.81-82).
}

A insegurança, porém, não impede os servos de continuarem atrelados a um jugo do qual eles mesmos se beneficiam. Abraão, depois de superado o episódio de Isaac, verá dobradas as suas riquezas, assim como Job, ao terminar de sofrer a sanha probatória enfurecida da divindade, lucrará com mais bens e uma nova família, substitutos daqueles que lhe foram roubados pela desgraça. Tais casos ilustram a oportuna reflexão de Caim, ao assistir a partilha dos despojos pelos israelitas vencedores no confronto com os madianitas: "É bem possível que o pacto de aliança que alguns afirmam existir entre deus e os homens não contenha mais que dois artigos, a saber, tu serves-nos a nós, vocês servem-me a mim" (SARAMAGO, 2009, p.107).

Ao Deus que contempla seus leais títeres com as devidas recompensas, nem tudo, porém, é permitido. Apesar de endossar algumas premissas básicas do autoritarismo (ARENDT, 2000), quais sejam as arbitrariedades, a impulsividade nas decisões e a agressividade à oposição, a divindade primordial não pode se arrogar a exclusividade no exercício do poder, pois explica muito mal sua falta de controle sobre certas pessoas e fatos. Assim é que não identifica Caim entre os agregados da família de Abraão quando lhe 
vai anunciar o nascimento de um filho, nem tampouco dá conta do por que do intenso tráfego do protagonista pelo tempo e espaço:

Tens viajado muito, pelos vistos, Assim é, senhor, mas que não que fosse por minha vontade, pergunto-me até se estas constantes mudanças que me tem levado de um presente a outro, ora no passado, ora no futuro, não serão também obra tua. Não, nada tenho que ver com isso, são habilidades primárias que me escapam, truques para épater le bourgeois, para mim o tempo não existe, Admites então que haja no universo uma outra força, diferente e mais poderosa que a tua, É possível, não tenho por hábito discutir transcendências ociosas (SARAMAGO, 2009, p.150).

As prerrogativas de destruição que conformam a personalidade autoritária também se revelam limitadas para o tirano celeste de Caim. Ainda que arrase Sodoma e Gomorra naquilo que classifica como um "trabalho" bem feito, "limpo e eficaz, sobretudo definitivo" (SARAMAGO, 2009, p.149), Deus não detém poder algum sobre a capacidade de insurreição do homem, derribando-se parte de sua fachada autoritarista diante da impossibilidade de controlar o pensamento e cercear as opiniões daqueles que não temem enfrentá-lo. Leiamos a conversa da divindade com Josué às vésperas da tomada de Gibeon pelos hebreus, quando o comandante israelita inquire sobre a possibilidade de Deus favorecê-lo na batalha por meio da alteração dos trânsitos celestes:

\footnotetext{
Manda parar a terra, que seja o sol a parar ou que pare a terra, a mim é-me indiferente desde que possa acabar com os amorreus. Se eu fizesse parar a terra, não se acabariam só os amorreus, acabava-se o mundo (...) Pensei que o funcionamento da máquina do mundo dependesse apenas da tua vontade, senhor, Já demasiado eu a venho exercendo, e outros em meu nome, por isso é que há tanto descontentamento, gente que me virou as costas, alguns que vão ao ponto de negar a minha existência, Castiga-os, estão fora da minha lei, fora da minha alçada, não lhes posso tocar, é que a vida de um deus não é tão fácil quanto vocês creem, um deus não é senhor daquele contínuo quero, posso e mando que se imagina, nem sempre se pode ir direito aos fins, há que se rodear (SARAMAGO, 2009, p.118-119).
}

Consciente dos limites de seu poder, mas nem por isso menos enfatuada com ele, a deidade, como todo autoritarista que se preze, cerca-se de asseclas eficientes, tanto quanto se esmera na trama de ardis, exercitando magistralmente aquilo que Arendt (2000) aponta como a arte totalitária de mentir consistentemente. Vejamos o que conversam Deus e Caim no momento da construção da arca de Noé:

Não sabes a força que têm os anjos, com um só dedo levantariam uma montanha, o que me vale é serem tão disciplinados, não fosse isso e já teriam organizado um complô para me deporem, Como satã, disse caim, Sim, como satã, mas a este já lhe encontrei a maneira de o trazer contente, de vez em quando deixo-lhe uma vítima nas mãos para que se entretenha e isso lhe basta (SARAMAGO, 2009, p.153).

Mestre em tramóias, senhor de epifanias portentosas, jogador compulsivo no que tange aos arcanos do destino humano, o Deus de Caim consolida sua faceta infantil na distribuição de engodos como o que aplica a Satã. Faz-se crer todo poderoso, mas revela a fragilidade de uma autoridade deturpada, a qual somente se sustenta mediante a colaboração de acólitos interesseiros ou atemorizados. Na sua luta contra a força da palavra, da contestação plena de sentido, comum a todos os regimes autoritários, deixa cair 
a máscara e revela suas numerosas fragilidades de criança, a falta de domínio pleno sobre sua pretensa criação luzindo em primeiro lugar.

\title{
2 A sagração da violência
}

A uma divindade como a de Caim, não é estranha a ideia da violência, na medida em que, como salienta Arendt (1985), esta última acompanha de perto todo o exercício subvertido da autoridade.

Abordando a estreita relação entre poder e violência, Dadoun (1998, p.81-82) comenta:

\begin{abstract}
Somos de imediato surpreendidos pela proximidade entre poder e violência. Sempre, de alguma forma, o poder afronta e utiliza a violência, e esta, em troca, sempre exprime uma certa forma de poder. Mais ainda: existe uma extraordinária familiaridade entre poder e violência, vínculos tão estreitos, presos de tal maneira às suas estruturas, que se chega a pensar que o único problema real do poder é a violência e que a única verdadeira finalidade da violência é o poder não importa sob que forma. Mais um esforço de união, ou de desarticulação, e será permitido dizer que a violência se mantém no coração do poder e o poder se mantém no coração da violência.
\end{abstract}

É com vistas à manutenção de seu poder que o Deus do romance de Saramago encarna uma personagem sanguinária, vingativa e injusta, para quem atitudes infanticidas e misóginas não passam de satisfações a uma vaidade desmedida e a um anseio de domínio pleno sobre tudo e todos. Esta deidade autocentrada se afina ao retrato pintado no Antigo Testamento bíblico, que desvenda uma imagem divina acorde aos primórdios de um povo algo selvagem, cuja principal meta é sobrepujar seus inimigos e conquistar a terra prometida. De acordo com Magalhães (2007, p.18):

\begin{abstract}
A divindade da tradição judaico-cristã assume feições ciumentas, vingativas, beligerantes. As grandes características das culturas plasmaram a tradição judaico-cristã, mas também receberam decisivas influências desta. Em uma sociedade guerreira emerge a divindade autoritária e militar, em uma cultura com forte pensamento sacrificial, a divindade salva ao matar ou permitir a morte.
\end{abstract}

E mais: "A divindade na qual cremos é aquela que resgatou o mundo do caos e que terá prazer mórbido em destruir tudo antes de vir o paraíso" (MAGALHÃES, 2007, p.20).

Por outro lado, é contra este biblicamente proclamado "Senhor dos Exércitos" que se insurge Caim, ao questionar o sofrimento daqueles que são justos e inocentes. Ele também foi inocente um dia, querendo agradar o senhor através da oferenda dos frutos de seu trabalho. Porém, ao ter sua oferta preterida sem qualquer razão, ao passo que a de seu irmão é aceita, deixa-se contaminar pelo mesmo egocentrismo e fúria que regem a divindade, tornando-se assassino fratricida e assim participando da mesma sanha destrutiva que orienta os desígnios inescrutáveis do Altíssimo. Consumido pela violência praticada, mas paradoxalmente protegido pelo mesmo deus a quem afronta, um Caim de vida errante passa a deslindar as injustiças do mundo, denunciando as veleidades de "um senhor que cresce em glória e esplendor na medida em que seu povo mata, destrói e se apodera das cidades inimigas" (CARLOS; SALLES, 2011, p.3).

A glória do todo poderoso celeste exige inauditos empreendimentos de suas criaturas: a divindade pode solicitar tranquilamente a um pai que sacrifique em seu nome o único filho - caso de Abraão - ou castigar com as maiores desgraças, apenas a título de 
testagem da fé, seu mais leal servidor - caso de Job. Também pode dispor sobre a punição de cidades inteiras sem distinguir entre inocentes e culpados na massa de seus moradores. Ao comentar sobre o futuro castigo dos habitantes de Sodoma com Abraão, a quem Deus prometera poupar os inocentes que encontrasse na cidade, Caim declara que "existam inocentes ou não, sodoma será destruída, e se calhar esta mesma noite" (SARAMAGO, 2009 , p.94). E realmente o foi, malgrado as promessas vazias da divindade ao primeiro dos patriarcas. A este, estarrecido, resta escutar a conclusão de Caim:

Penso que havia inocentes em sodoma e nas outras cidades que foram queimadas, Se os ouvesse, o senhor teria cumprido a promessa que me fez de lhes poupar a vida. As crianças, disse caim, aquelas crianças estavam inocentes, Meu deus, murmurou Abraão e a sua voz foi como um gemido, Sim, será o teu deus, mas não foi o delas (SARAMAGO, 2009, p.97).

Para um deus que não se furta a incendiar cidades com crianças inocentes, a eventual idolatria de seu povo escolhido é definitivamente algo que precisa ser castigado a ferro e fogo. A ira divina sublinha as ordens dadas pelo Senhor a Moisés, quando este retorna de seu retiro no Monte Sinai, para se deparar com os israelitas adorando o bezerro de ouro:

Eis o que diz o senhor, deus de israel, pegue cada um em uma espada, regressem ao acampamento e vão de porta em porta, matando cada um de vocês o irmão, o amigo, o vizinho. E foi assim que morreram cerca de três mil homens. O sangue corria entre as tendas como uma inundação que brotasse do interior da própria terra, como se ela própria estivesse a sangrar, os corpos degolados, esventrados, rachados de meio a meio, jaziam por toda a parte, os gritos das mulheres e crianças eram tais que deviam chegar ao cimo do monte Sinai onde o senhor estaria se regozijando com sua vingança. Caim mal podia acreditar no que seus olhos viam. Não bastavam sodoma e gomorra arrasadas pelo fogo, aqui, no sopé do monte sinai, ficara patente a prova irrefutável da profunda maldade do senhor, três mil homens mortos só porque ele tinha ficado irritado com a invenção de um suposto rival em forma de bezerro (SARAMAGO, 2009, p.101).

O Deus dos exércitos também alimenta as atrocidades da guerra, incentivando a pilhagem, o estupro e a chacina dos adversários de seu povo dileto. Na luta contra os madianitas, o Senhor ordena aos israelistas que abatam todos os inimigos, incluindo mulheres e crianças. Quando da volta dos vitoriosos, ao perceber que os soldados haviam poupado todas as mulheres, Moisés ordena irritado:

Por que não mataram vocês também as mulheres, essas que fizeram com que os israelitas se afastassem do senhor e adorassem o deus baal, maldade que provocou uma grande mortandade no povo do senhor, ordeno-vos pois que voltem para atrás e matem todos os rapazes e todas as raparigas [as crianças], e as mulheres casadas, quanto as outras, as solteiras, guardem-nas para vosso uso (SARAMAGO, 2009, p.105).

Percebemos assim que os prosélitos desta divindade dos massacres, como Moisés e Josué, não deixam de se coadunar à divina fúria destrutiva, assumindo quase que prazerosamente a condução das retaliações orquestradas pela deidade. $\mathrm{O}$ último patriarca aqui citado, célebre capitão dos hebreus na conquista de Canaã, vinga-se magistralmente da fraqueza cobiçosa de Acan, que rouba e esconde em sua casa alguns tesouros dos cananeus, quando a ordem do Senhor é que todos os bens dos inimigos sejam destruídos: 
Josué tomou então acan com a prata, o manto e a barra de ouro, mais os filhos e filhas, bois, jumentos e ovelhas, a tenda e tudo que ele tinha, e levou-os até o vale açor. Chegados lá, josué disse, Já que foste a nossa desgraça, pois por tua culpa morreram trinta e seis israelitas, que o senhor agora te desgrace a ti. Então, todas as pessoas o apedrejaram e, em seguida, lançaram-nos ao fogo, a eles e a tudo que tinham (...) Assim se acalmou a ira de deus, mas, antes que o povo se dispersasse, ainda se ouviu a estentória voz a clamar, Ficam avisados, quem mas fizer, paga-mas, eu sou o senhor (SARAMAGO, 2009, p.114-115).

O mesmo Josué, imbuído de zelo extremo no acato das ordens do Senhor, encampa a destruição em massa da cidade de Ai:

Foram doze mil, entre homens e mulheres, os que morreram naquele dia, ou seja, toda a população de ai, pois dali ninguém conseguiu escapar, não houve um só sobrevivente. Josué mandou enforcar numa árvore o rei de ai e deixou-o ficar pendurado até à tarde. Ao pôr do sol, deu ordem para retirarem o cadáver e o lançarem à porta da cidade (SARAMAGO, 9009, p.115).

Aos fiéis cumpridores de suas ordens, a divindade recompensa com o farto botim resultante das cidades destruídas, o que leva Caim a refletir:

Está visto que a guerra é um negócio de primeira ordem, talvez seja mesmo o melhor de todos a julgar pela facilidade com que se adquirem do pé para a mão milhares e milhares de bois, ovelhas, burros e mulheres solteiras, a este senhor terá de chamar-se um dia deus dos exércitos, não lhe vejo outra utilidade (SARAMAGO, 2009, p.107).

E assim, sequazes ensandecidos tanto pelo temor das idiossincrasias divinas quanto pela cobiça, reiteram continuamente a espiral de violência gerada a partir da vontade do Senhor dos Exércitos. De acordo com Girard (1998, p.107):

O mecanismo da violência coletiva pode ser descrito como um círculo vicioso; uma vez que a comunidade aí penetra, é impossível sair. Este círculo pode ser definido em termos de vingança e represálias ou suscitar várias descrições psicológicas. Enquanto houver, no seio da comunidade, um capital de ódio e de desconfiança acumulados, os homens continuarão a se servir dele, fazendo-o frutificar. Cada um se prepara contra a provável agressão do vizinho, e interpreta seus preparativos como a confirmação de suas tendências agressivas. De forma mais geral, é necessário reconhecer na violência uma natureza mimética tão intensa que ela não consegue morrer por si própria uma vez que tenha se instalado na comunidade.

Mimesis tecida, sobretudo, a partir de um Deus que funda a criação sob o estigma da violência: ele cerca o casal original de interditos que, uma vez desrespeitados, suscitarão a expulsão de Adão e Eva do paraíso, condenando-os a "ganhar o pão com o suor de seu rosto" - as agruras do trabalho - e a mulher, considerada sedutora perversa, a parir com dores e sofrer a dominação do macho. Mais tarde, a mesma divindade, desgostosa com as atitudes dos homens, decidirá aniquilar toda a vida na terra, afogando sua criação sob as águas do dilúvio.

Contra este criador violento se insurge Caim, mas sua insurreição acaba por movêlo, paradoxalmente, à incorporação de uma parcela da própria violência contra a qual se rebela. Ele mata o irmão por ciúmes da preferência divina e, ainda que recuse participar do assassinato do marido de Lilith, mais adiante irá reiterar seu comportamento assassino, exterminando um a um os familiares de Noé durante sua viagem na arca, atitude ditada 
pela vontade de sabotar os planos divinos de repovoamento do planeta após o dilúvio. Desta forma, o mesmo Caim que se insurge não deixa de mimetizar a divindade que condena, na medida em que cede ao seu furor destrutivo, divisando nos "poços sem fundo" (SARAMAGO, 2009, p.153) da natureza divina a sua própria imagem:

\footnotetext{
Não faltará quem pense que o malicioso caim anda a divertir-se com a situação, jogando ao gato e ao rato com seus inocentes companheiros de navegação, aos quais, como o leitor já terá suspeitado, tem vindo a eliminar um a um. Equivocar-se-á quem assim creia. Caim debate-se com a sua raiva contra o senhor como se estivesse preso nos tentáculos de um polvo, e estas suas vítimas de agora não são mais, como abel já tinha sido no passado, que outras tantas tentativas de matar deus (SARAMAGO, 2009, p.169).
}

Segundo a Bíblia, o primogênito de Adão e Eva chega a constituir família e construir uma cidade, legando ao mundo descendentes que se esmerarão na criação da música e da metalurgia, ao que Dadoun (1998, p.21), comenta: "Estranha gênese esta que inscreve a civilização humana sob o sinal perene de Caim, o criminoso!". No entanto, o romance de Saramago retira do assassino de Abel toda e qualquer prerrogativa fundacionista: se faz um filho na amante Lilith, será o marido dela quem irá criá-lo como seu. Mímico que imita odiando sua imitação e imitado, Caim não pode matar o odiado criador que estranhamente lhe poupou a vida, sentenciando-o a vagar errante e roubandolhe mesmo o direito de morrer. A violência que ele condena, mas que acaba incorporando, converte-o em um ser estéril em uma terra estéril: no mundo despido de toda a vida humana que se segue ao fim do cataclisma aquático, continuará parindo seu discurso veemente contra a divindade, único consolo para quem se vê apenas como um corpo ao qual a deidade devorou o espírito.

\section{Considerações finais}

Ao finalizarmos nossa incursão pela releitura saramaguiana da Bíblia, fica-nos a sensação de que poder e violência se incorporaram à parturição do ser humano, enquanto sujeito e objeto de um relacionamento às avessas com a divindade.

O Deus de Caim se erige como um pater familias simultaneamente incômodo e desacomodado, na medida em que projeta veleidades egocêntricas e infantilizadas como ritos de poder, deturpando o papel de provedor benévolo e justo que lhe é esperado. Paradoxo ao Deus-pai, criador e senhor de todas as coisas, não pode se instituir como mestre de todos os seres, quando sua própria identidade é marcada pelo exercício dúbio da autoridade, pela exigência de preitos e submissões que não se conformam à verdadeira majestade, uma vez que a grandeza divina se resume a ouropéis de prestidigitações epifânicas, nada legando à providência nas misérias humanas.

A esta representação de uma deidade carnavalizada, para cunhar um dos conceitoschave na poética bakhtiniana, é forçoso ajustar um homem contestador e iconoclasta, criatura que reivindica a verdade sob a máscara do divino, desvendando as incongruências de um poder que somente se cristaliza ao solapar a vontade de seus apaniguados.

Porém, a contestação não se dá sem a dor da experiência na seara do tempo. Entre o Caim ignorante da verdadeira natureza divina e o irmão de Abel, assassino pioneiro sob a égide do ciúme e da incompreensão, reside a descoberta pelo homem do poder destrutivo da divindade, um poder que emana do criador para sua criatura, tornando-se ela vítima e algoz. Ferido pelo poder do Senhor, Caim mergulha no poço sem fundo da divindade, ao descobrir também em si o poder de semear violência. É assim que do primeiro fratricídio 
brota o abate dos irmãos de condição humana, concretizado no extermínio da família de Noé. E se consolida a representação da violência como mimesis, grassando a autodestruição de Caim em seu embate contínuo com um Deus-pai que lhe roubou o direito de amá-lo e respeitá-lo, para deixar-lhe somente o vazio de reiterar o ódio ad aeternum em palavra e ato.

\section{REFERÊNCIAS}

ADORNO, T. Introdução à "A Personalidade Autoritária" (1950). Disponível em: <http://adorno.planetaclix.com> Acesso em: 25 nov. 2011.

ARENDT, H. Da violência. Brasília: Editora da UNB, 1985.

ARENDT, H. Origens do Totalitarismo. São Paulo: Companhia das Letras, 2000.

CARLO, P. S.; SALLES, W. F. Caim de José Saramago: um possível diálogo entre crentes e descrentes. In: ANAIS DO ENCONTRO DE INICIAÇÃO CIENTÍFICA E I ENCONTRO DE INICIAÇÃO EM DESENVOLVIMENTO TECNOLÓGICO E INOVAÇÃO DA PUC-CAMPINAS,16. Campinas: PUC, 2011. Disponível em: <http://www.puc-campinas.edu.br/.../2011820_11415_926968992_resesu.pdf> Acesso em: 26 nov. 2011.

CROCHIK, J. L. A personalidade narcisita segundo a Escola de Frankfurt e a ideologia da racionalidade tecnológica. Disponível em: <http://www.revistasusp.sibi.usp.br/ pdf/psicousp/v1n2/a05v1n2.pdf> Acesso em: 26 nov. 2011.

DADOUN, R. A violência: ensaio acerca do "homo violens". Rio de Janeiro: DIFEL, 1998. GIRARD, R. A violência e o sagrado. São Paulo: Paz e Terra, 1998.

MAGALHÃES, A. C. Violência, símbolo e religião: relação entre monoteísmo e violência. Estudos de Religião, São Paulo, n.32, p.12-21, jan./jun. 2007. Disponível em: $<$ https://www.metodista.br/revistas/revistas-ims/index.php/ER/.../202> Acesso em: $1 \mathrm{dez}$. 2011.

PERISSINOTTO, R. Hannah Arendt, poder e a crítica da tradição. Lua Nova, São Paulo, n.61, p.115-138, 2004. Disponível em: 〈http://www.scielo.br/pdf/in/n61/a07n61.pdf> Aceso em: 29 nov. 2011.

SARAMAGO, J. Caim. São Paulo: Companhia das Letras, 2009.

SEREJO, L. Poder e violência. Revista Em Foco em Educação e Filosofia, São Luís do Maranhão, v.1, p.19-28, 2008. Disponível em: <http://www.educacaoe filosofia.uema.br/v1/3doc> Acesso em: 1 dez. 2011.

Recebido em: 14 de janeiro de 2012.

Aprovado em: 08 de abril de 2012. 